\title{
PERFORMANCE OF SOME PEA CULTIVARS AND HYBRIDS AND PHYLOGENETIC RELATIONSHIPS BASED ON ISOESTERASE POLYMORPHISM AND MULTIVARIATE ANALYSIS OF DEVELOPMENTAL AND YIELD CHARACTERS \\ Swidan, Suzan A. \\ Horticultural Crops Research Institute, Agricultural Research Centre, Giza, Egypt
}

\section{ABSTRACT}

Twenty-five local and exotic pea cultivars and three $F_{1}$ hybrids were used in this study to evaluate their performance and their phylogenetic relationships based on both the polymorphism of esterase molecular forms differentially expressed in root, stem, leaf and seed tissues and the multivariate analysis of eight developmental, yield and quality characters. This study was carried out, in El-Kassasein Horticultural Research Station during the winter seasons of 2004/2005, 2005/2006 and 2006/2007.

Least significant differences, showed that almost all pea cultivars and hybrids had considerable variation for all the eight characters where they showed a wide range of mean values for all of these characters. $F_{1}\left(P_{6} \times P_{13}\right)$ had the highest mean values for four out of the eight characters. It had an average of $241.3 \mathrm{gm}$ for pods weight per plant and an average of 92.3 for number of pods per plant.

The isoesterase polymorphism showed clearly a distinguished differential display of esterase molecular forms over the four tissues during the ontogeny of the pea plant. A total of $9,9,15$ and 16 esterase molecular forms were, respectively, obtained from root, stem, leaf and seed tissues over the twenty-eight pea cultivars and hybrids.

Dendrogram constructed based on the transformed mean values of eight polygenic traits grouped the twenty-eight pea populations on four separate clusters. The three $F_{1}$ hybrids occupied a unique cluster with the hightest cluster mean values for five out of the eight characters especially those for pods weight, number of pods per plant and yield per feddan. This suggested that these three hybrids could be considered a promising base population for a successful selection program for improving pea yield.

The results demonstrated the higher discriminatory power and clustering based on multivariate analysis of eight developmental, yield and quality polygenic traits than that based on the differential expression of esterase isozymes in four tissues. Both dendrograms showed no parallelism between the two clustering systems.

Key words : Dendogram, Esterase , Isozymes, Multivariate Analysis, Pea , Pisum sativum , Phylogenetics, Polymorphism, Yield.

\section{INTRODUCTION}

Pea (Pisum sativum Linn.) is an important vegetable crop grown almost all year round in various regions the world over. However, its productivity has become static over the years even if the total planted area has increased tremendously. This plateau is attributable to the lack of improved cultivars for different agroclimatic conditions. In order to further increase the yield potential in pea, it is desirable to either evaluate the performance of various cultivars in different regions or to develop new genotypes through recombination breeding and selection (Sood and Kalia, 2006). 


\section{Swidan, Suzan A.}

Multivariate analysis based on polygenic characters was used by many investigators for grouping and to identify the phylogenetic relationships among pea cultivars and landraces in the purpose for the efficient designation of effective breeding programs (Amurrio et al., 1994).

Ultilization of isozyme polymorphism to discriminate and identify pea cultivars using isozyme expression in different tissues has been applied by Posvec and Gariga, (2002). Differential expression of isozymes over plant tissues and, also, isozyme polymorphism have been used by many investigators to identify the genetic distances and the phylogenetic relationships among different legumes (Santalla et al., 2002 and Smutkupt et al., 2006). Pectin methyl esterase (PME) has an activity level in immature peas of about 2.5 times that found in the most mature peas, (Collins, 1970). This PME was found to be tightly correlated, both spatially and temporally, with border cell separation in pea root caps, root elongation and systematic cellular morphology development. The demethylation of pectin by pectin methylesterase plays a key role in cell wall metabolism. Pectin as a polymer is a major constituent of cell walls. Pectolytic enzymes, esterases, can solubolise cell walls (Collmer and Keen 1986; Koutojansky, 1987). Pectin methylesterase (PME), although, it does not by itself solubolize cell walls, but it regulates cell wall degradation by several mechanisms (Goldberg et al., 1992), by reducing $\mathrm{pH}$ through the release of a proton when methoxyl groups of pectin are converted to carboxyl groups. This change in $\mathrm{pH}$ controls the activity of other cell wall-degrading enzymes that are active at low $\mathrm{pH}$ and thereby to facilitate cell expansion and growth (Nari et al., 1986) and /or cell separation (Koutojansky, 1987; Wen et al., 1999).

This study aimed to evaluate the performance of twenty-eight pea cultivars and hybrids and to study the parallelism between their phylogenetic relationships based on either the polymorphism of esterase molecular forms differently expressed in four tissues or on the multivariate analysis of eight developmental, yield and quality characters.

\section{MATERIALS AND METHODS}

Two field experiments were carried out in the Experimental Farm of ElKassasein Horticultural Research Station, Ismailia Governorate.

\section{Evaluation experiment:}

The experiment was achieved twice over two successive seasons. Twenty-five pea (Pisum sativm L.) local and exotic cultivars and three $F_{1}$ hybrids were used in this study. These were Arica $(A)$ as $P_{1}$, Onward as $P_{2}$, Jo 1086 as $P_{3}$, Ambassador $(A)$ as $P_{4}$, Jurbo as $P_{5}$, Arica as $P_{6}$, Syrian as $P_{7}$, Jumbo as $P_{8}$, Atol as $P_{10}$, Hunter as $P_{11}$, Top pod as $P_{12}$, Ambassador as $P_{13}$, Master as $P_{14}$, Toledo Sugar as $P_{15}$, Sugar Luv as $P_{16}$, Penine as $P_{17}$, Oregon Sugar Real as $\mathrm{P}_{18}$ Mammoth as $\mathrm{P}_{19}$, Sugar E.M (Doddy) as $\mathrm{P}_{20}$, Filanon (Nun 0060) as $P_{21}$ Little Marvel as $P_{24}$ Perfection as $P_{25}$ Sugar Snap (BS0017) as $\mathrm{P}_{26}$, Cascadia as $\mathrm{P}_{27}$ and Sugar Ann (BS0016) as $\mathrm{P}_{28}$. These local and exotic cultivars were kindly obtained from the Self-pollinated Vegetable Research Department, Horticultural Crops Research Institute. The three $F_{1}$ hybrid crosses $P_{13} \times P_{24}, P_{6} X P_{13}$ and $P_{13} X P_{6}$ were achieved during the winter season of 2004/2005. Both the three $F_{1}$ hybrids and the 25 local and exotic 
cultivars were sown, in the Experimental Farm at El-Kassasein Horticultural Research Station for evaluation in each of the two successive winter seasons 2005/2006 and 2006/2007.

Both seeds of the three $F_{1 s}$ and of the twenty-five local and exotic cultivars were sown in October of the two successive seasons 2005/2006 and 2006/2007 in a randomized complete block design with three replications. In both seasons of evaluation, similar agricultural procedures were applied for all entries. Two seeds per hill were sown in a single hill for each dripper. The drippers were $20 \mathrm{~cm}$ apart and the irrigation lines were $60 \mathrm{~cm}$ width. Each plot was $6 \mathrm{~m}^{2}$. The treatments were similar for all entries under study in both seasons.

In each season, ten plants from each entry overall replications were randomly chosen to measure both the developmental and yield characters. The developmental characters recorded were; stem length $(\mathrm{cm})$, number of leaves per plant and number of branches per plant. The yield characters were the weight of green pods per plant $(\mathrm{gm})$, number of pods per plant and yield per feddan. Pod quality characters measured were the average weight of pod, and average pod length (cm).

Isozyme electrophoresis:

Samples from each of the 25 cultivars and the three $F_{1}$ hybrids were randomly taken. These samples were used to study the isoesterase molecular froms in root, stem, leaf and seed tissues after forty days from sowing date.

Esterase (Est.) isozyme system, which has given the designation of EC 3.1.1.1 in the report of commission of enzymes (International Union of Biochemists, 1978), was screened in all the plant materials at the Biotechnology lab., El-Kassasein Horticultural Research Station, Horticultural Crops Research Institute.

Six samples, from each of the four tissues, were collected of all the cultivars and the $F_{1}$ hybrids. Isozyme extraction buffer of esterase isozymes and procedures were applied according to Tanksley and Orton (1983).

Equal protein concentrations were determined according to Bradford (1976) and were used for sample preparation and sample loading in gels. The buffers used in preparing gels and samples as well as sample loading and electrophoretic conditions were described by Guirgis et al., (1996). Procedures of Kahler and Alard (1970) were applied with modifications suggested by Tanksley and Rick (1980) for detecting non specific esterase isozymes.

\section{Statistical Analysis:}

The statistical analysis was carried out on the blot mean basis of the pooled mean over both seasons. The least significant difference (LSD) test was used to evaluate differences between pea cultivars and hybrid mean values, according to Snedecor and Cochran (1972).

\section{Genetic Distances and Clustering Analysis Based on Polymorphism of} Esterase Molecular Forms:

To study clustering pattern among the studied pea cultivars and hybrids based on band differences of esterase molecular forms expressed in four different tissues of the pea plant, the data generated from all the twenty-eight 


\section{Swidan, Suzan A.}

entries, were recorded according to binary values $(1,0)$ for presence and absence, respectively. Genetic distance, calculated as an Euclidean metric distance, was computed between all pairs of populations. Hierarchical clustering procedure was applied using Ward's methods as developed by Hair et al. (1987).

The phylogenetic relationships of clustering patterns are presented as dendrogram constructed on linkage distance basis. The matrix of similarity was analysed by the unweighted pair group method using the arithmetic average (UPGMA), as suggested by Sneath and Sokal (1973).

Genetic Distances and Clustering Analysis Based on Multivariate Analysis of Eight Developmental, Yield and Quality Characters:

Means over the two seasons of all the eight developmental, yield and quality characters for the studied pea cultivars and hybrids were subjected to a multivariate analysis (Johnson and Wichern, 1988). The data were analysed using hierarchical Euclidean cluster analysis. The original mean values of eight characters were transformed to uncorrelated variables using dispersion matrix. Hierarchical clustering procedure were applied using complete linkage method. The cluster analysis and dendrogram construction were performed with SPSS (1995).

\section{RESULTS AND DISCUSSION}

\section{Performance of Developmental Characters in Pea Cultivars and $F_{1}$ Hybrids:}

Data in Table (1), showed that the pea cultivar Mammoth $(198.7 \mathrm{~cm})$ followed by Syrian $(108 \mathrm{~cm})$ had the highest mean value for stem length. Meanwhile, the cultivar Hunter $(45 \mathrm{~cm})$ followed by Jurbo $(50 \mathrm{~cm})$ had the least stem length value.

However, the $F_{1}$ hybrid $(13 \times 24)$ segregated transgressively and it had higher $(103 \mathrm{~cm})$ stem length value than those of both parental values, indicating that this $F_{1}$ hybrid had more increasing genes controlling taller stem length. However, more decreasing genes were observed for this character in the $F_{1}(6 \times 13)$. Since, it showed lower value $(57 \mathrm{~cm})$ than that of either parents; $P_{6}(79.2 \mathrm{~cm})$ and $P_{13}(93 \mathrm{~cm})$.

For number of leaves per plant, the cultivar Syrian had the highest mean value (91.7) but Hunter had the least number of leaves per plant (23.3). The $F_{1}(13 \times 24)$ showed to have the highest value (128.7) that exceeded the values for both parents which were 50.3 and 45.7 for $P_{13}$ (Ambassador) and $\mathrm{P}_{24}$ (Little Marvel), respectively. This clearly suggest that more increasing genes controlling this character were accumulated in this $F_{1}$ hybrid. However, intermediate values of the $F_{1}$ hybrids $F_{1}(6 \times 13)$ and $F_{1}(13 \times 6)$ were observed for this character. This might suggest that the parental cultivar P24 "Little Marvel" is the parent containing most of increasing genes for this character.

For number of branches per plant, both cultivars Atol and Toledo had the highest mean value (5.0) for this character but both Hunter and Little Marvel had the least mean value (1.33). However, the $F_{1}$ hybrid (6X13) "Arica $X$ Ambassador" had the highest mean value for number of branches per plant (6.67) followed by the $F_{1}$ (13X24) "Ambassador X Little Marvel" (5.33) where 
J. Agric. Sci. Mansoura Univ., 32 (6), june, 2007

T1 


\section{Swidan, Suzan A.}

boh hybrids exceeded the respective mean values of their parents (Table 1). This might suggest that more increasing genes were present in these $F_{1}$ hybrids.

\section{Performance of Yield and Quality Characters in Pea Cultivars and $F_{1}$ Hybrids:}

In regard to the range between the mean values of yield and quality characters, the least significant difference either at $1 \%$ or $5 \%$ level of probability, clearly suggests the presence of some sort of significant difference among most of either the cultivars or the $F_{1}$ hybrids for these characters. This suggests that these cultivars and hybrids could construct a good base population for beginning a hybrid and selection program for improving these characters (Table 1).

For yield characters, the cultivar Oregon Sugar, had the highest mean values for both pod weight (139.3 g) and yield per feddan (5.65 Ton). Moreover, the highest mean value for number of pods per plant was obtained by the cultivar Arica (50). Meanwhile, the least values of both pods weight (31.9 g.) and pods number per plant (8.0) were found for the cultivar Master. The cultivar Sugar Snap had the least value for total yield per Feddan (1.17 Ton). Hussain and Badshah (2002) reported that the maximum number of pods per plant in their pea material was 19.3.

It is worthy to mention that all the three $F_{1}$ hybrids exceeded the highest values of all the cultivars, including their parents, for all the yield aforementioned characters. This might suggest that this could be due to the presence of more increasing genes, controlling these characters, in these $F_{1}$ hybrids.

For pod characters over all cultivars, the mean values of pod weight ranged from (2.63 g.) for "Jo 1086" to (1.10g.) for Arica (A). The mean values of pod length ranged from $(14.6 \mathrm{~cm})$ for Master cultivar to $(6.00 \mathrm{~cm})$ for both Cascadia and Arica (A).

In the three $F_{1}$ hybrids, intermediate mean values between those of parental cultivars of each hybrid were obtained for pod weight, and in only $F_{1}$ (6X13) and $F_{1}$ (13X6) for pod length. Meanwhile, the value of pod length exceeded those of either parents for the $F_{1}$ hybrid (13 X 24).

The results, in Table (1), indicated none of the twenty-five cultivars or the three hybrids showed to have the highest mean values for all the characters. This suggests that these cultivars could be used as a base population for a promising pea breeding program through hybridization followed by selection. However, the highest mean values for total yield per feddan, (6.36 Ton), pod weight per plant $(241.3 \mathrm{~g}$.), number of pods per plant (92.3) and number of branches per plant (6.67) were obtained by the $F_{1}$ hybrid (P6xP13) "Arica $X$ Ambassador". This $F_{1}$ hybrid showed to have the highest mean values of both number of branches per plant and the three yield characters which exceeded those of either the respective parental cultivars and the other two hybrids of this study.

Differential Display and Polymorphism of Isoesterase Molecular Forms in Four Tissues of Pea Plants:

Differential display of esterase molecular forms over four tissues showed that the highest polymorphism was expressed in seed tissues as 16 
isoesterase molecular forms which were observed in the zymograms of seed tissues of each of $P_{13}, P_{27}$ (Photograph 1B and Figure 1B) and $F_{1}\left(P_{6} \times P_{13}\right)$ (Photograph $1 \mathrm{C}$ and Fig. 1C).

Comparing isoesterase polymorphism in the other three tissues, over the twenty-five cultivars, the highest number of isoesterase molecular forms, of seed tissue exceeded those obtained in either root, stem or leaf tissues. A total of 9,9 and 15 molecular forms were observed to be the highest number of variants in root $\left(P_{4}\right)$ stem $\left(P_{28}\right)$ and leaf $\left(P_{28}\right)$ tissues, respectively (Fig. $1 \mathrm{~A}$ and $1 \mathrm{C})$.

Differential display over the four tissues in the three $F_{1}$ pea hybrids, showed also that seed tissues had more isoesterase molecular forms (16 isoforms) than those expressed in any of the other three tissues (Fig. 1C).

Esterase as a pectolytic enzyme interferes in most changes in the cell wall of the plant cell during development of different immature tissues. It can solubolize cell walls (Collmer and Keen, 1986; Koutojansky, 1987). Pectin methylesterase (PME), although it does not by itself solublize cell walls, but it regulates cell wall degradation by several mechanisms (Goldberg et al., 1992), either by reducing $\mathrm{pH}$ by the release of a proton when methoxyl groups of pectin are converted to carboxyl groups. This change in $\mathrm{pH}$ controls the activity of other cell wall-degrading enzymes that are active at low $\mathrm{pH}$ and thereby facilitate cell expansion and growth (Nari et al., 1986) and / or cell separation (Koutojansky, 1987; Wen et al., 1999).

Data in photograph (1) and Figure (1) indicated that more differentially displayed esterase molecular forms were expressed in seed tissues followed by those in leaf tissues either in pea cultivars or hybrids. This indicated that isoesterases are needed in all tissues during the ontogeny of pea plant but more isoesterases are needed during the development of seeds and leaves.

However, differential display of polymorphism of isoesterases over the four tissues suggests that pea cultivars and hybrids of our material could be identified and discriminated from each other. Using isozyme polymorphism in different pea tissues to discriminate and identify pea cultivars was also applied by Posvec and Gariga (2002).

Similarity Coefficients, Genetic Distances and Clustering Analysis Based on Differential Expression of Esterase Molecular Forms:

Only polymorphic bands were used in the construction of a binary matrix, reflecting the presence or absence of esterase isozymes in different tissues of the cultivars and $F_{1}$ hybrids. The similarity coefficient values among cultivars and hybrids based on band polymorphism of esterase isozymes over the differences in four different tissues are presented in Table (2). The similarity coefficients ranged from (81) between $\mathrm{P}_{20}$ and $\mathrm{P}_{21}$ (distantly related) to $(0.0)$ between the cultivar Sugar Ann $\left(P_{28}\right)$ and each of $P_{7}$ and $P_{8}$. The genetic distances based on the similarity index were calculated as squared total number of esterase isozymes band differences, between pea cultivars and hybrids over the four tissues and are presented in Table (3). The lowest genetic distance value (8) was found between the cultivars Sugar E.M. $\left(P_{20}\right)$ and Filanon $P_{21}$. Meanwhile, the highest genetic distance value (45) was found between the cultivar Sugar Ann $\left(\mathrm{P}_{28}\right)$ and each of the cultivars Syrian $\left(\mathrm{P}_{7}\right)$ and Jumbo $\left(\mathrm{P}_{8}\right)$. Also, genetic distances based on differential expression 
Swidan, Suzan A.

FOTO1 
J. Agric. Sci. Mansoura Univ., 32 (6), june, 2007

F1 
Swidan, Suzan A.

T2

4542 
J. Agric. Sci. Mansoura Univ., 32 (6), june, 2007

F2 
Swidan, Suzan A.

T3

4544 
of isozymes over plant tissues were evaluated and applied by Santalla et al., (2002) and Smutkupt et al., (2006).

The dendrogram produced from genetic distances between pea cultivars and hybrids based on the differential expression of esterase isozymes in four tissues is shown in Figure (2). Based on the extent of relative dissimilarity among pea cultivars and hybrids, they were grouped into two clusters. Cut off point at 60 dissimilarity points was fixed as minimum dissimilarity.

Cluster I consisted of 10 populations of the cultivars and hybrids. It involved all the three $F_{1}$ hybrids $P_{13} \times P_{24}, P_{13} \times P_{6}$ and $P_{6} \times P_{13}$ and seven cultivars. These seven cultivars included the two cultivars; $P_{13}$ and $P_{24}$ which were involved in the three hybrids. However, the other parental cultivar $\mathrm{P}_{6}$ as well as other seventeen cultivars were found to be the eighteen members of cluster II.

Genetic Diversity of Phylogenetic Relationship among Twenty-eight Pea Cultivars and $F_{1}$ Hybrids Based on Multivariate Analysis of Eight Developmental, Yield and Quality Characters:

The mean performance of the twenty-five pea cultivars and the three $F_{1}$ hybrids presented in Table (1) showed a wide range of variation among these cultivars and hybrids over eight developmental, yield and quality characters. The mean values of these eight characters were used as a base for a hierarchical Euclidean Cluster analysis. A matrix of genetic distances for the twenty eight pea cultivars and hybrids is presented in Table (4). The genetic distances for all the 378 pairs ranged from 0.10 to 1.79 . The highest genetic distance value (1.79) was obtained between the cultivar Master $\left(P_{14}\right)$ and the $F_{1}$ hybrid $\left(P_{6} \times P_{13}\right)$. This was followed by a distance of 1.61 between the cultivar Sugar Snap $\left(\mathrm{P}_{26}\right)$ and $\mathrm{F}_{1}\left(\mathrm{P}_{6} \mathrm{XP}_{13}\right)$.

This indicated that the $F_{1}\left(P_{6} X_{13}\right)$ is the most divergent one out of all other pea cultivars and $F_{1}$ hybrids. The mean performance of developmental, yield and quality characters in Table (1) is in agreement with this result. Meanwhile, according to diversity based on esterase molecular forms in four tissues, the highest genetic distance was found between the cultivar Sugar Ann $\left(P_{28}\right)$ and each of Syrian $\left(P_{7}\right)$ and Jumbo $\left(P_{8}\right)$. This might suggest that there is no parallelism between the phylogenetic relationship based on isoesterase molecular forms of four tissues and that based on eight developmental, yield and quality characters. Such polygenic characters strongly affected the distribution of pea cultivars and $F_{1}$ hybrids over the clusters of the phylogenetic tree.

The dendrogram produced from genetic distances based on the developmental, yield and quality characters showed a grouping pattern and distribution of the 28 pea cultivars and hybrids on four clusters (Fig. 3). This clustering pattern is based on the extent of relative dissimilarity among, pea cultivars and hybrids. Cut off point of 0.9 genetic distance was fixed as minimum dissimilarity. 
Swidan, Suzan A.

T4

4546 
J. Agric. Sci. Mansoura Univ., 32 (6), june, 2007

F3 
Swidan, Suzan A.

T5

4548 
Cluster I consisted of three pea cultivars; $\mathrm{P}_{1}, \mathrm{P}_{6}$ and $\mathrm{P}_{7}$. Cluster II, was the largest cluster, it included fourteen pea cultivars. Cluster III consisted of eight pea cultivars. Cluster analysis united the three $F_{1}$ hybrids; $F_{1}\left(P_{13} X\right.$ $\left.P_{24}\right), F_{1}\left(P_{6} \times P_{13}\right)$ and $F_{1}\left(P_{13} \times P_{6}\right)$ into single cluster (IV). Data of this cluster analysis indicated the distribution of pea cultivars over three clusters. The

existence of such a wide genetic diversity suggests improvability of pea by developing new genotypes through recombination breeding. Such finding was corre sponding with what reported by Sood and Kalia (2006).

\section{Mean Performance of Developmental Yield and Quality Characters Over Clusters of Both Clustering Systems:}

Mean values of the eight characters over the two clusters produced of the clustering system based on isoesterase molecular forms or over the four clusters which constructed on the basis of multivariate analysis of the eight characters are presented in Table (5). Cluster IV of the second clustering system showed to have the highest mean values for five out of the eight characters; the three yield characters, number of leaves and number of branches per plant. This strongly suggests that the members of this cluster can share in constructing an effective breeding program to improve pea. Similar conclusion was obtained by Amurrio et al., (1994). Meanwhile, cluster III showed to have the highest mean values over the rest three characters; stem length and both of the pod characters. None of the two clusters of the clustering based of esterase molecular forms showed to have any of the highest values for any of the eight characters. This might suggest that there is no parallelism between the two clustering systems.

\section{REFERENCES}

Amurrio, J.M.; A.M.de Ron and A.C. Zeven. 1994. Numerical taxonomy of Iberian pea landraces based on quantitative and qualitative characters. Euphytica, 82(3): 195-205.

Bradford, M.M. 1976. A rapid and sensitive method for quantitation of microgram quantities of protein utilizing the principle of protein-dye binding. Anal. Biochem. 72:248-254.

Collins, J.L. 1970. Pectin methylesterase activity in southern peas (Vigna sinensis). J. Food Sci. 35(1): 1-4.

Collmer, A., and N.T. Keen. 1986. The role of pectic enzymes in plant pathogenesis. Annu. Rev. Phytopathol. 24, 383-409.

Goldberg, R., M. Pierron, L. Durand, and S. Mutaftshiev. 1992. In vitro and in situ properties of cell wall pectinmethylesterases from mung bean hypocotyls. J. Exp. Bot. 43, 41-46.

Guirgis, A.A., A.A. Mahmoud and A.M. El-Fouly 1996. Molecular diversity, identity, genetic distance and heterozygosity in cucumber populations. Zagazig J. Agric. Res. 23(5): 763-772.

Hair, J.F.; R.E. Anderson and R.L. Tatham. 1987. Multivariate Data Analysis with Readings. MacMillan Publi. Co., New York, USA. 


\section{Swidan, Suzan A.}

Hussain S.A. and N. Badshah. 2002. Study of the adaptive behaviour of exotic pea (Pisum sativum L.) varieties under local conditions of Peshawar. Asian J. Pt. Sci.1 (5): 567-568.

International Union of Biochemists, 1978. Enzyme Nomenclature. Academic Press, New York, 606 pp.

Johnson, F.W. and N.F. Wichern. 1988. Applied Multivariate Statistical Analysis. $2^{\text {nd }}$ ed. Prentice-Hall, Englewood Cliffs, New York, USA.

Koutojansky, A. 1987. Molecular genetics of pathogenesis by soft-rot Erwininas. Annu. Rev. Phytopathol. 25, 405-430.

Kahler, A.L. and R.W. Allard. 1970. Genetics of isozyme variants in barley. I. Esterases. Crop. Sci., 10:444-448.

Nari, J., G. Noat, G. Diamantidis, M. Woudstra, and J. Ricard. 1986. Electrostatic effects and the dynamics of enzyme reactions at the surface of plant cells. III. Interplay between limited cell-wall autolysis, pectin methyl esterase activity and electrostatic effects in soybean cell wall. Eur. J. Biochem. 155, 199-210.

Posvec Z. and M. Gariga. 2000. Utilization of isozyme polymorphism for cultivar identification of 45 commercial peas (Pisum sativum L.). Euphytica, 113(3) 249-256.

Santalla, M.; A.P. Rodino; and A.M. DeRon. 2002. Allozyme evidence supporting southwestern Europe as a secondary centre of genetic diversity for the common bean. Theor. Appl. Genet. 104: 934-944.

Smutkupt, S.; S. Peyachoknagul; K., Kowitwanich; S. Onto; N., Thanananta; S. Julsrigival; W.; Kunkaew and V., Punsupa. 2006. Varietal determination and genetic relationship analysis of highland legumes using SRAP markers. SABRAO J. Breed. Genet., 38(1): 19-27.

Sneath P.H.A. and R.R. Sokal. 1973. Numerical Taxonomy. W.H. Freeman \& Co., San Francisco.

Snedecor, G.W. and W.W. Cochran. 1972. Statistical Methods, $6^{\text {th }}$ Ed. lowa State Univ., Ames, lowa, USA.

Sood, M. and P. Kalia. 2006. Gene action of yield-related traits in garden pea (Pisum sativum L.). SABRAO J. Breed. Genet., 38(1) 1-17.

SPSS. 1995. SPSS user's guide. SPSS Inc., USA.

Tanksley, S.D. and T.J. Orton 1983. Isozymes in Plant Genetics and Breeding. Part B. Elsevier, Amesterdam.

Tanksley, S.D. and C.M. Rick. 1980. Isoenzyme gene linkage map of the tomato: Applications in genetics and breeding. Theor. Appl. Genet., 57:161-170.

Wen, F.; Y. Zhu, and M.C. Hawes. 1999. Effect of pectin methylesterase gene expression on pea root development. Plant Cell, 11(6): 11291140. 


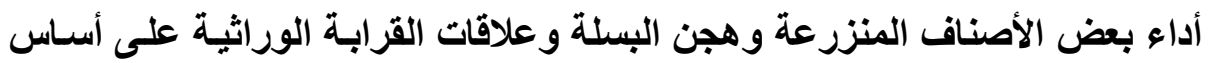

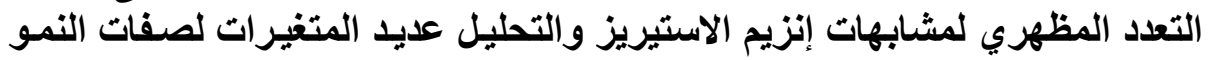

معهد بحوث المحاصيل البستانية ـ مركز البحوث الزراعية ـ جيزة - جمهورية مصر العربية

استخدم في هذه الدراسة خمسة و عشرون صنفا منزر عا من أصناف البسلة المحلية والأجنيبـة

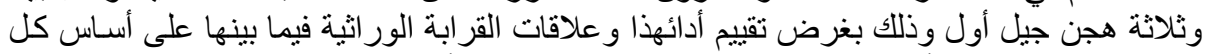

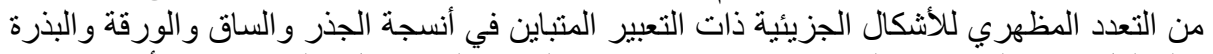

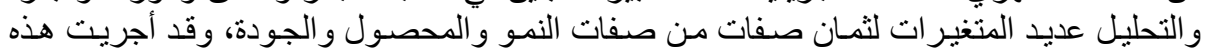

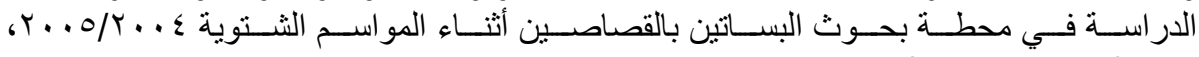

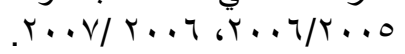

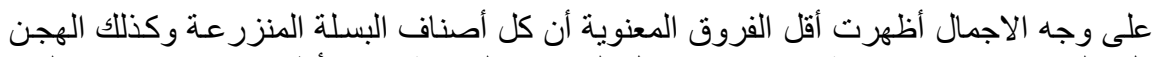

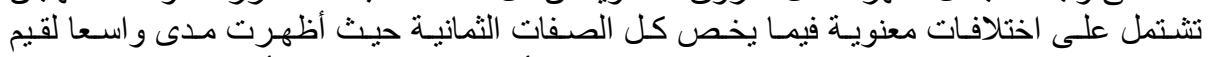
المنوسطات لكل من تلك الصفات، وقل وقد امتلك الهجين الأول

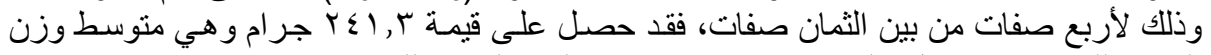

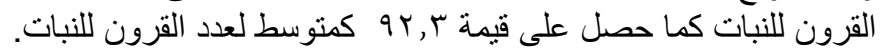

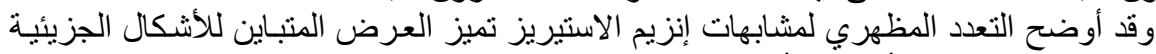

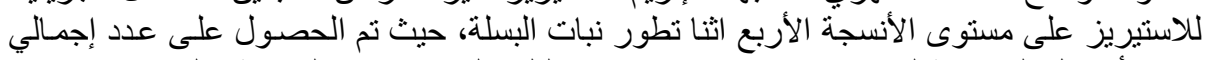

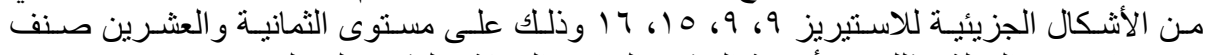

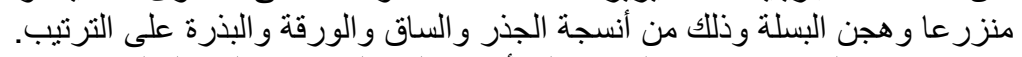

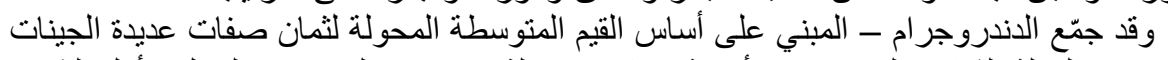

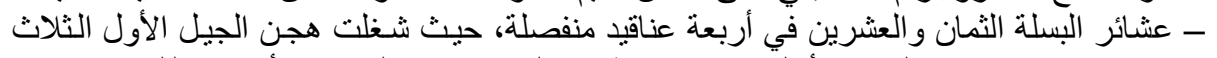

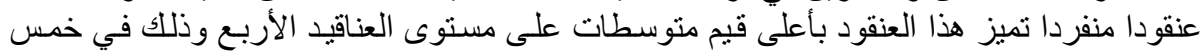

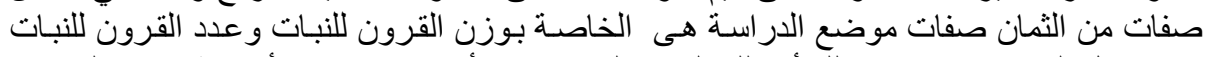

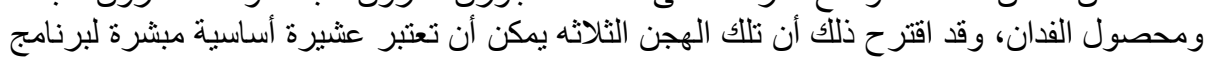
إنتخاب ناجح لتحسين المحصول النقان في نبات البسلة.

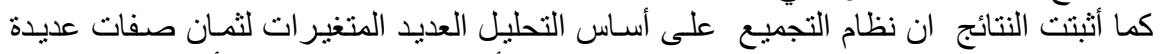

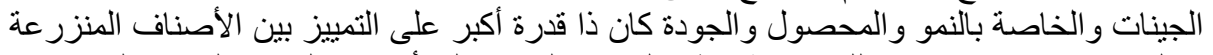

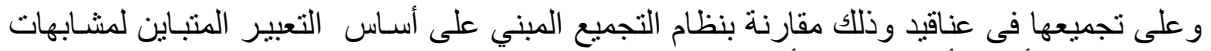

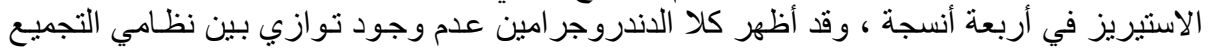
اللذين إنتعا في تلك الدراسة. 
Table 1 : Mean values of some developmental, yield and quality characters for local and exotic pea Cultivars and

\begin{tabular}{|c|c|c|c|c|c|c|c|c|}
\hline \multicolumn{2}{|l|}{$F_{1}$ hybrids . } & \multirow{2}{*}{\begin{tabular}{c|} 
No. \\
leaves/plant
\end{tabular}} & \multirow{2}{*}{$\begin{array}{l}\text { No. Branches/ } \\
\text { plant }\end{array}$} & \multicolumn{2}{|c|}{ Yield/plant } & \multirow[b]{2}{*}{ Yield Ton/Fed. } & \multicolumn{2}{|c|}{ Pod characters } \\
\hline Cultivar or Hybrid & $\begin{array}{c}\text { Stem length } \\
(\mathrm{cm})\end{array}$ & & & Pods wt (g) & No. pods & & Weight (g) & Length $(\mathrm{cm})$ \\
\hline 1 Arica $(A)$ & 67.8 & 58.3 & 3.33 & 47.9 & 28.0 & 1.92 & $\frac{1.10}{1.10}$ & 6.00 \\
\hline 2 On Ward & 90.0 & 44.0 & 2.67 & 77.0 & 23.0 & 2.09 & 2.10 & 8.00 \\
\hline 3 Jo 1086 & 82.7 & 32.7 & 1.67 & 52.2 & $\frac{23.0}{23.0}$ & 3.08 & $\frac{2.10}{2.63}$ & 6.93 \\
\hline 4 Ambassador (A) & 52.7 & 35.3 & 2.33 & 35.5 & 14.3 & 1.42 & 2.43 & 6.53 \\
\hline 5 Jurbo & 50.0 & 50.7 & 4.00 & 61.0 & 19.0 & 2.44 & $\frac{c .40}{2.21}$ & 8.00 \\
\hline 6 Arica & 79.2 & 70.0 & 3.33 & 74.4 & 50.0 & 2.86 & 1.32 & 6.07 \\
\hline 7 Syrian & 108.0 & 91.7 & 4.00 & 71.6 & 30.7 & 2.85 & 2.31 & 6.80 \\
\hline 8 Jumbo & 80.0 & 65.0 & 4.44 & 88.8 & 21.0 & 3.55 & 2.37 & 11.27 \\
\hline 10 Atol & 75.4 & 72.0 & 5.00 & 100.3 & 26.0 & 4.01 & 2.39 & 8.17 \\
\hline 11 Hunter & 45.0 & 23.3 & 1.33 & 35.0 & 35.7 & 2.20 & 1.54 & 8.03 \\
\hline 12 Top pod & 93.3 & 50.0 & 3.00 & 84.0 & 26.0 & 3.36 & 2.29 & 7.00 \\
\hline 13 Ambassador & 93.0 & 50.3 & 3.00 & 64.0 & 26.3 & 2.57 & 2.42 & 6.80 \\
\hline 14 Master & 53.3 & 28.0 & 1.67 & 31.9 & 8.0 & 1.28 & $\frac{2.76}{2.59}$ & 14.60 \\
\hline 15 Toledo sugars & 77.7 & 56.0 & 5.00 & 101.0 & 46.0 & 4.04 & 2.19 & 8.80 \\
\hline 16 Sugar Luv & 62.7 & 58.3 & 3.33 & 88.0 & 30.0 & 3.53 & 2.87 & 7.27 \\
\hline 17 Penine & 67.0 & 45.7 & 2.33 & 73.3 & 31.7 & 2.93 & 2.49 & 9.40 \\
\hline 18 Oregon sugar & 69.0 & 47.7 & 4.67 & 139.3 & 31.3 & 5.65 & 2.52 & 9.10 \\
\hline 19 Mammoth & 198.7 & 85.3 & 3.33 & 136.7 & 33.0 & 5.77 & 3.13 & 9.33 \\
\hline 20 Sugar E.M & 76.7 & 42.7 & 2.67 & 108.0 & 47.0 & 4.32 & 2.37 & 7.47 \\
\hline 21 Filanon (Nun0060) & 67.3 & 40.0 & 1.67 & 49.0 & 26.3 & 1.96 & 1.83 & 7.33 \\
\hline 24 Little Marvel & 92.0 & 45.7 & 1.33 & 63.6 & $\frac{20.5}{22.7}$ & 2.54 & 2.13 & 6.53 \\
\hline 25 Perfection & 87.3 & 52.7 & 3.33 & 71.7 & 27.7 & 2.87 & 2.48 & 6.60 \\
\hline 26 Sugar Snap (BS0017) & 59.0 & 36.0 & $\frac{0.06}{2.67}$ & 29.2 & 18.3 & 1.17 & 1.57 & 6.50 \\
\hline 27 Cascadia & 66.0 & 53.7 & 4.00 & 35.0 & 16.0 & 1.43 & 2.06 & 6.00 \\
\hline 28 Sugar Ann (BS0016) & 63.7 & 37.0 & 2.33 & 42.3 & 19.0 & 1.73 & 2.41 & 6.20 \\
\hline \multicolumn{9}{|l|}{ F1 Hybrids } \\
\hline F1 $(13 \times 24)$ & 103.0 & 128.7 & 5.33 & 203.3 & 56.7 & 4.33 & 2.34 & 7.07 \\
\hline F1 $(6 \times 13)$ & 57.0 & 67.0 & 6.67 & 241.3 & 92.3 & 6.36 & 2.37 & 6.40 \\
\hline F1 $(13 \times 6)$ & 93.0 & 61.0 & 3.33 & 222.3 & 84.0 & 6.35 & 2.15 & 6.47 \\
\hline \multicolumn{9}{|l|}{ LSD } \\
\hline $1 \%$ & 6.75 & 6.14 & 1.565 & 16.15 & 4.90 & 0.369 & 0.308 & 1.155 \\
\hline $5 \%$ & 5.08 & 4.45 & 1.135 & 11.81 & 3.60 & 0.268 & 0.114 & 0.840 \\
\hline
\end{tabular}


Table 2 : Similarity coefficients among the twenty-eight pea cultivars and F1 hybrids based on esterase electrophoretic molecular forms differentially expressed in root, stem, leaf and seed tissues.

\begin{tabular}{|c|c|c|c|c|c|c|c|c|c|c|c|c|c|c|c|c|c|c|c|c|c|c|c|c|c|c|c|}
\hline \begin{tabular}{|c|}
$\begin{array}{c}\text { Cultivar } \\
\text { or Hybrid }\end{array}$ \\
\end{tabular} & 2 & 3 & 4 & 5 & 6 & 7 & 8 & 10 & 11 & 12 & 13 & 14 & 15 & 16 & 17 & 18 & 19 & 20 & 21 & 24 & 25 & 26 & 27 & 28 & \begin{tabular}{|c|} 
F1 \\
$(13 \times 24)$ \\
\end{tabular} & $\begin{array}{c}\mathrm{F} 1 \\
(6 \times 13)\end{array}$ & $\begin{array}{c}F 1 \\
(13 \times 6)\end{array}$ \\
\hline 1 & 0.5 & 0.68 & 0.28 & 0.30 & 0.59 & $\mid 0.14$ & 0.14 & 0.39 & 0.41 & 0.51 & 0.75 & 0.32 & 0.27 & 0.46 & 0.49 & 0.62 & 0.58 & 0.510 & 0.54 & $|0.67|$ & 0.50 & 0.61 & 0.71 & 0.61 & 0.46 & \begin{tabular}{|l|l|}
0.76 \\
\end{tabular} & 0.64 \\
\hline 2 & & 0.45 & 2.65 & 0.59 & 0.50 & 0.19 & 0.13 & 0.23 & 0.35 & 0.23 & 0.53 & $0.17 \mid$ & 0.31 & 0.50 & 0.48 & 0.59 & 0.60 & 0.54 & 0.58 & 0.49 & 0.33 & 0.25 & 0.37 & 0.46 & 0.31 & 0.51 & 0.38 \\
\hline 3 & & & 0.32 & 0.27 & 0.68 & 0.19 & 0.05 & 0.41 & 0.48 & 0.45 & 0.75 & $0.22 \mathrm{C}$ & 0.25 & 0.43 & 0.46 & 0.59 & 0.59 & 0.410 & 0.49 & 0.69 & 0.36 & 0.41 & 0.56 & 0.61 & 0.37 & 0.73 & 0.68 \\
\hline 4 & & & & 0.56 & 0.38 & 0.37 & 0.10 & 0.23 & 0.29 & 0.22 & 0.32 & 0.23 & 0.29 & 0.48 & 0.62 & 0.35 & 0.54 & 0.540 & 0.36 & 0.37 & 0.40 & 0.45 & 0.47 & 0.41 & 0.33 & 0.42 & 0.44 \\
\hline 5 & & & & & 0.34 & 0.30 & 0.07 & 0.24 & 0.26 & 0.31 & 0.32 & 0.310 & 0.34 & 0.51 & 0.32 & 0.33 & 0.56 & 0.650 & 0.56 & 0.36 & 0.58 & 0.45 & 0.46 & 0.44 & 0.32 & 0.51 & 0.35 \\
\hline 6 & & & & & & 0.16 & 0.09 & 0.41 & 0.43 & 0.53 & 0.70 & 0.36 & 0.27 & 0.57 & 0.59 & 0.56 & 0.66 & 0.450 & 0.48 & 0.68 & 0.40 & 0.47 & 0.54 & 0.53 & 0.44 & \begin{tabular}{|l|}
0.67 \\
\end{tabular} & 0.58 \\
\hline 7 & & & & & & & 0.09 & 0.21 & 0.25 & 0.32 & 0.12 & 0.17 & 0.16 & 0.24 & 0.14 & 0.23 & 0.27 & 0.22 & 0.19 & 0.20 & 0.21 & 0.27 & 0.29 & 0.00 & 0.24 & \begin{tabular}{|l|}
0.24 \\
\end{tabular} & 0.26 \\
\hline 8 & & & & & & & & 0.36 & 0.26 & 0.15 & 0.06 & 0.51 & 0.51 & 0.23 & 0.11 & 0.06 & 0.06 & 0.06 & 0.06 & 0.08 & 0.33 & 0.17 & 0.24 & 0.00 & 0.05 & 0.11 & 0.08 \\
\hline 10 & & & & & & & & & 0.70 & 0.60 & 0.46 & 0.32 & 0.19 & 0.37 & 0.40 & 0.39 & 0.38 & 0.21 & 0.28 & 0.53 & 0.19 & 0.55 & 0.45 & 0.38 & 0.24 & $\begin{array}{l}0.40 \\
\end{array}$ & 0.45 \\
\hline 11 & & & & & & & & & & 0.52 & 0.53 & 0.33 & 0.30 & 0.37 & 0.35 & 0.35 & 0.42 & 0.22 & 0.21 & 0.56 & 0.14 & 0.37 & 0.39 & 0.34 & 0.28 & \begin{tabular}{|l|}
0.42 \\
\end{tabular} & 0.48 \\
\hline 12 & & & & & & & & & & & 0.47 & 0.59 & 0.26 & 0.41 & 0.44 & 0.33 & 0.41 & 0.29 & 0.32 & 0.59 & 0.32 & 0.63 & 0.59 & 0.46 & 0.34 & \begin{tabular}{|l|}
0.48 \\
\end{tabular} & 0.51 \\
\hline 13 & & & & & & & & & & & & 0.30 & 0.33 & 0.49 & 0.57 & 0.75 & 0.66 & 0.60 & 0.61 & 0.77 & 0.39 & 0.46 & 0.56 & 0.66 & 2.51 & $\begin{array}{ll}0.78 \\
\end{array}$ & 0.67 \\
\hline 14 & & & & & & & & & & & & & 0.43 & 0.17 & 0.32 & 0.14 & 0.24 & 0.32 & 0.28 & 0.32 & 0.39 & 0.42 & 0.37 & 0.32 & 0.32 & 0.31 & 0.32 \\
\hline 15 & & & & & & & & & & & & & & 0.34 & 0.34 & 0.27 & 0.36 & 0.36 & 0.30 & 0.33 & 0.44 & 0.34 & 0.28 & 0.33 & 0.24 & 0.30 & 0.29 \\
\hline 16 & & & & & & & & & & & & & & & 0.58 & 0.46 & 0.69 & 0.52 & 0.46 & 0.51 & 0.47 & 0.51 & 0.54 & 0.48 & 0.33 & $\begin{array}{l}0.54 \\
\end{array}$ & 0.50 \\
\hline 17 & & & & & & & & & & & & & & & & 0.52 & 0.68 & 0.57 & 0.58 & 0.49 & 0.44 & 0.40 & 0.45 & 0.44 & 0.37 & \begin{tabular}{|l|}
0.46 \\
\end{tabular} & 0.44 \\
\hline 18 & & & & & & & & & & & & & & & & & 0.72 & 0.60 & 0.65 & 0.63 & 0.40 & 0.42 & 0.48 & 0.56 & 0.41 & 0.19 & 0.50 \\
\hline 19 & & & & & & & & & & & & & & & & & & 0.75 & 0.74 & 0.66 & 0.61 & 0.44 & 0.55 & 0.56 & 0.45 & 0.61 & 0.56 \\
\hline 20 & & & & & & & & & & & & & & & & & & & 0.81 & 0.49 & 0.76 & 0.43 & 0.51 & 0.52 & 0.44 & 0.56 & 0.51 \\
\hline 21 & & & & & & & & & & & & & & & & & & & & 0.49 & 0.66 & 0.42 & 0.48 & 0.51 & 0.47 & \begin{tabular}{|l|}
0.50 \\
\end{tabular} & 0.40 \\
\hline 24 & & & & & & & & & & & & & & & & & & & & & 0.37 & 0.56 & 0.59 & 0.59 & 0.41 & \begin{tabular}{|l|}
0.67 \\
\end{tabular} & 0.67 \\
\hline 25 & & & & & & & & & & & & & & & & & & & & & & 0.41 & 0.46 & 0.41 & 0.31 & \begin{tabular}{|l|}
0.48 \\
\end{tabular} & 0.41 \\
\hline 26 & & & & & & & & & & & & & & & & & & & & & & & 0.78 & 0.63 & 0.36 & 0.56 & 0.54 \\
\hline 27 & & & & & & & & & & & & & & & & & & & & & & & & 0.73 & 0.46 & \begin{tabular}{|l|l|}
0.66 \\
\end{tabular} & 0.64 \\
\hline 28 & & & & & & & & & & & & & & & & & & & & & & & & & 0.44 & $\begin{array}{ll}0.68 \\
\end{array}$ & 0.60 \\
\hline$F 1(13 \times 24)$ & & & & & & & & & & & & & & & & & & & & & & & & & & \begin{tabular}{|l|}
0.39 \\
\end{tabular} & 0.40 \\
\hline$F 1(6 \times 13)$ & & & & & & & & & & & & & & & & & & & & & & & & & & & 0.74 \\
\hline
\end{tabular}




\section{Swidan, Suzan A.}

Table 3 : Mean proximity matrix of squared Genetic distances according to esterase molecular forms differentially expressed in root, stem, leaf and seed tissues of the twenty-eight pea cultivars and F1 hybrids.

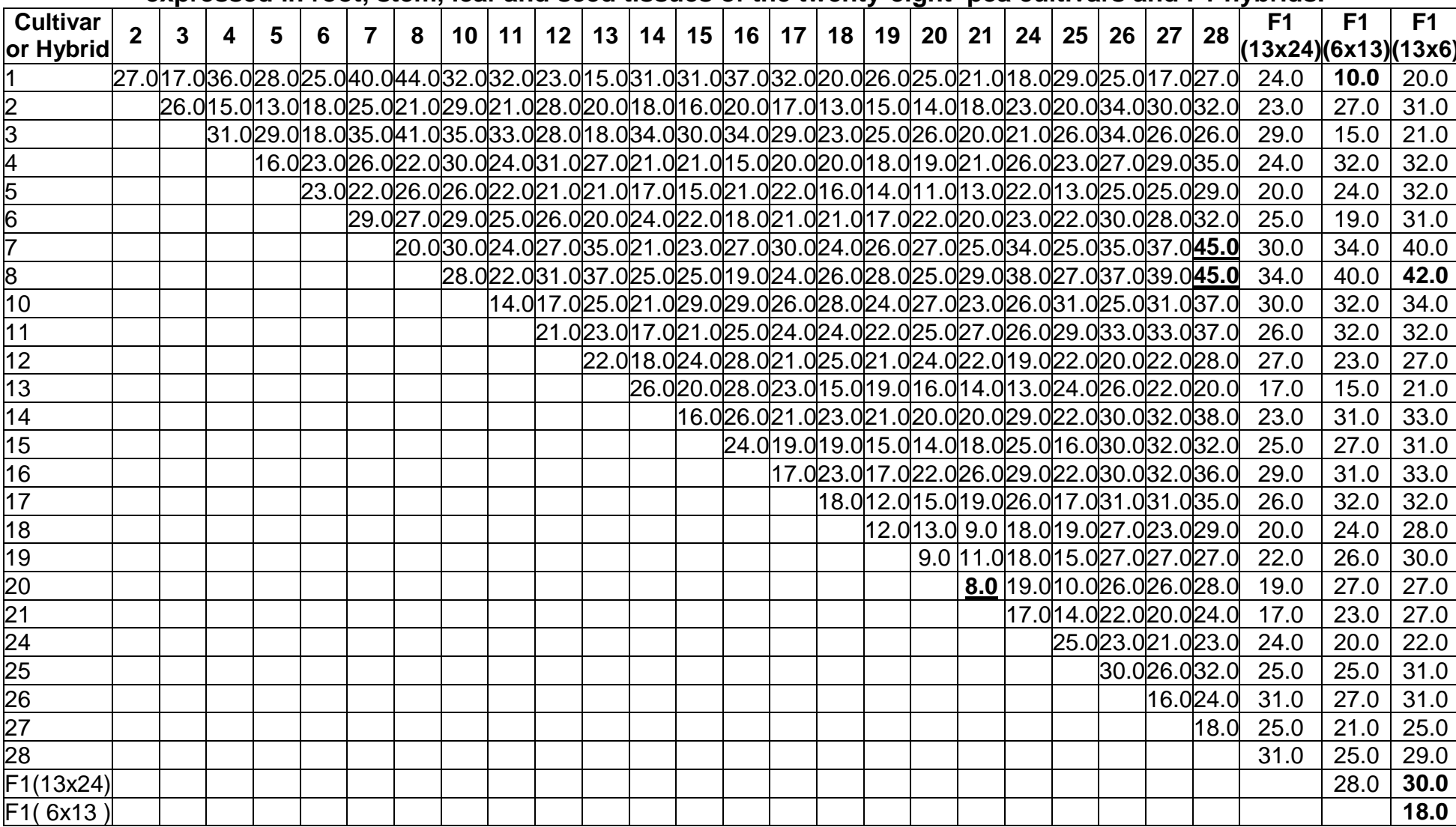




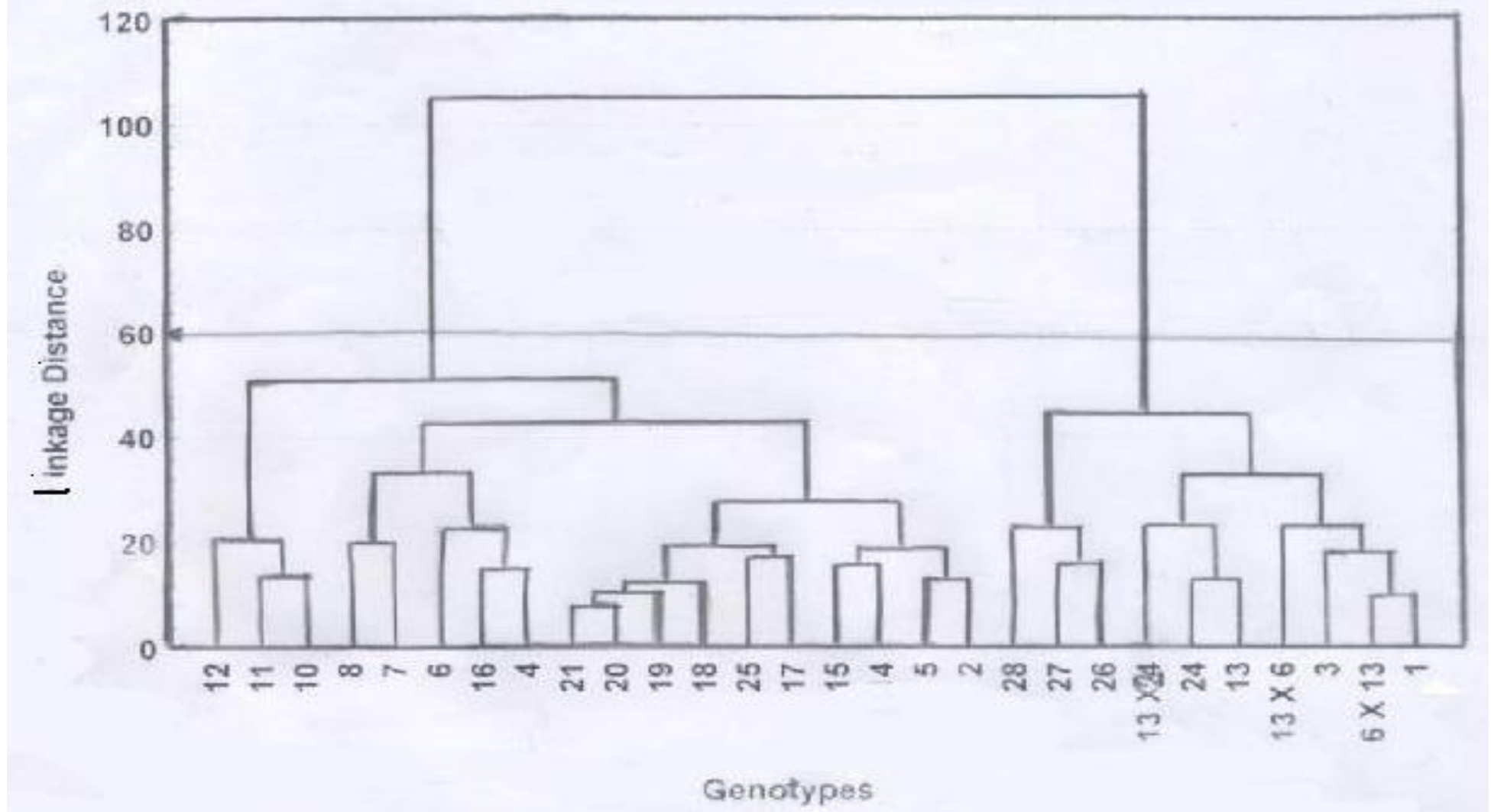

Fig. 2: Linkage dendrogram for twenty-eight local and exotic pea cultivars and F1 hybrids based on differential expression of esterase molecular forms in four tissues. 
Swidan, Suzan A.

Table 4: Genetic distances matrix (transformed data) of squared Genetic distances based on mean values of eight developmental, yield and quality characters of the twenty-eight pea cultivars and F1 hybrids.

\begin{tabular}{|c|c|c|c|c|c|c|c|c|c|c|c|c|c|c|c|c|c|c|c|c|c|c|c|c|c|c|c|}
\hline $\begin{array}{l}\text { Cultivar } \\
\text { or } \\
\text { Hybrid }\end{array}$ & 1 & 2 & 3 & 4 & 5 & 6 & 7 & 8 & 10 & 11 & 12 & 13 & 14 & 15 & 16 & 17 & 18 & 19 & 20 & 21 & 24 & 25 & 26 & 27 & 28 & $\begin{array}{c}F 1 \\
(13 \times 24)\end{array}$ & $\begin{array}{c}\mathrm{F} 1 \\
(6 \times 13)\end{array}$ \\
\hline 2 & 0.41 & & & & & & & & & & & & & & & & & & & & & & & & & & \\
\hline 3 & 0.62 & 0.32 & & & & & & & & & & & & & & & & & & & & & & & & & \\
\hline 4 & 0.52 & 0.33 & 0.34 & & & & & & & & & & & & & & & & & & & & & & & & \\
\hline 5 & 0.43 & 0.30 & 0.45 & 0.36 & & & & & & & & & & & & & & & & & & & & & & & \\
\hline 6 & \begin{tabular}{|l|}
0.32 \\
\end{tabular} & \begin{tabular}{|l|} 
\\
\end{tabular} & \begin{tabular}{|l|}
0.65 \\
\end{tabular} & 0.68 & 0.52 & & & & & & & & & & & & & & & & & & & & & & \\
\hline 7 & \begin{tabular}{|l|}
0.55 \\
\end{tabular} & \begin{tabular}{|l|}
0.47 \\
\end{tabular} & \begin{tabular}{|l|}
0.61 \\
\end{tabular} & $\mid 0.66$ & 0.47 & 0.45 & & & & & & & & & & & & & & & & & & & & & \\
\hline 8 & \begin{tabular}{|l|}
0.65 \\
\end{tabular} & 0.46 & 0.60 & 0.66 & 0.37 & 0.62 & 0.43 & & & & & & & & & & & & & & & & & & & & \\
\hline 10 & $\begin{array}{l}0.65 \\
\end{array}$ & \begin{tabular}{|l|}
0.53 \\
\end{tabular} & \begin{tabular}{|l|}
0.64 \\
\end{tabular} & \begin{tabular}{|l|}
0.71 \\
\end{tabular} & 0.40 & 0.56 & 0.36 & 0.26 & & & & & & & & & & & & & & & & & & & \\
\hline 11 & $\begin{array}{l}0.48 \\
\end{array}$ & $\begin{array}{l}0.44 \\
\end{array}$ & 0.46 & 0.44 & 0.54 & 0.58 & 0.80 & 0.77 & 0.84 & & & & & & & & & & & & & & & & & & \\
\hline 12 & 0.49 & 0.23 & 0.30 & 0.46 & 0.33 & 0.45 & 0.38 & 0.39 & 0.39 & 0.55 & & & & & & & & & & & & & & & & & \\
\hline 13 & \begin{tabular}{|l|}
0.47 \\
\end{tabular} & \begin{tabular}{|l|}
0.18 \\
\end{tabular} & \begin{tabular}{|l|}
0.27 \\
\end{tabular} & 0.36 & 0.30 & 0.48 & $0.37 \mathrm{C}$ & $0.44 \mathrm{C}$ & 0.45 & 0.53 & 0.15 & & & & & & & & & & & & & & & & \\
\hline 14 & \begin{tabular}{|l|}
0.87 \\
\end{tabular} & \begin{tabular}{|l|} 
\\
\end{tabular} & \begin{tabular}{|l|} 
\\
\end{tabular} & 0.57 & 0.66 & 0.99 & 0.94 & 0.72 & 0.93 & 0.66 & 0.76 & 0.70 & & & & & & & & & & & & & & & \\
\hline 15 & 0.64 & 0.55 & 0.66 & 0.76 & 0.47 & 0.48 & 0.47 & 0.35 & 0.26 & 0.77 & 0.42 & 0.49 & 0.96 & & & & & & & & & & & & & & \\
\hline 16 & 0.64 & 0.40 & \begin{tabular}{|l|}
0.38 \\
\end{tabular} & \begin{tabular}{|l|}
0.51 \\
\end{tabular} & 0.34 & 0.57 & 0.42 & 0.38 & 0.34 & 0.67 & 0.26 & 0.29 & 0.78 & 0.41 & & & & & & & & & & & & & \\
\hline 17 & 0.56 & 0.26 & \begin{tabular}{|l|}
0.27 \\
\end{tabular} & 0.40 & 0.34 & 0.54 & 0.52 & 0.41 & 0.51 & 0.45 & 0.26 & 0.26 & 0.57 & 0.50 & 0.28 & & & & & & & & & & & & \\
\hline 18 & \begin{tabular}{|l|} 
\\
\end{tabular} & 0.71 & 0.73 & 0.90 & 0.63 & 0.75 & 0.68 & 0.45 & 0.37 & 0.93 & 0.53 & 0.65 & 1.04 & 0.36 & 0.48 & 0.61 & & & & & & & & & & & \\
\hline 19 & 1.20 & 0.96 & 0.96 & 1.21 & 1.06 & 1.03 & $0.77 \mathrm{C}$ & 0.81 & 0.79 & 1.29 & 0.80 & 0.88 & 1.30 & 0.83 & 0.84 & 0.930 & 0.77 & & & & & & & & & & \\
\hline 20 & \begin{tabular}{|l|}
0.66 \\
\end{tabular} & \begin{tabular}{|l|}
0.47 \\
\end{tabular} & \begin{tabular}{|l|}
0.43 \\
\end{tabular} & $\mid 0.66$ & 0.53 & $0.50 \mathrm{C}$ & $0.56 c$ & 0.52 & 0.48 & 0.60 & 0.31 & 0.41 & 0.89 & 0.38 & 0.33 & 0.340 & 0.44 & 0.81 & & & & & & & & & \\
\hline 21 & 0.38 & 0.24 & 0.33 & 0.29 & 0.41 & 0.50 & $0.62 C$ & 0.64 & 0.70 & 0.24 & 0.39 & 0.34 & 0.61 & 0.70 & 0.53 & 0.330 & 0.851 & 1.14 & 0.54 & & & & & & & & \\
\hline 24 & 0.49 & \begin{tabular}{|l|}
0.24 \\
\end{tabular} & \begin{tabular}{|l|}
0.22 \\
\end{tabular} & \begin{tabular}{|l|}
0.36 \\
\end{tabular} & 0.47 & 0.54 & $0.56 c$ & 0.62 & 0.67 & 0.41 & 0.30 & 0.27 & 0.68 & 0.69 & 0.47 & 0.320 & 0.80 & 0.98 & 0.48 & \begin{tabular}{|l|}
0.21 \\
\end{tabular} & & & & & & & \\
\hline 25 & 0.99 & \begin{tabular}{|l|}
0.67 \\
\end{tabular} & \begin{tabular}{|l|}
0.72 \\
\end{tabular} & \begin{tabular}{|l|}
0.87 \\
\end{tabular} & 0.78 & 0.94 & 0.70 & 0.58 & 0.74 & 0.99 & 0.66 & 0.65 & 0.77 & 0.75 & 0.70 & 0.640 & 0.83 & 0.67 & 0.76 & 0.850 & \begin{tabular}{|l|}
0.76 \\
\end{tabular} & & & & & & \\
\hline 26 & 0.31 & 0.35 & 0.50 & 0.29 & 0.40 & 0.56 & 0.68 & 0.71 & 0.76 & 0.36 & 0.52 & 0.44 & 0.67 & 0.77 & 0.65 & 0.510 & 0.96 & 1.29 & 0.72 & 0.250 & \begin{tabular}{|l|c|}
0.42 & $\mathrm{C}$ \\
\end{tabular} & \begin{tabular}{|l|}
0.96 \\
\end{tabular} & & & & & \\
\hline 27 & 0.36 & 0.35 & 0.52 & 0.32 & 0.25 & 0.54 & 0.49 & 0.56 & 0.56 & 0.58 & 0.44 & 0.34 & 0.74 & 0.63 & 0.51 & 0.500 & 0.84 & 1.16 & $0.68 \mid c$ & $0.41 \mathrm{C}$ & $0.48 \mid \mathrm{C}$ & $0.87 \mid c$ & 0.30 & & & & \\
\hline 28 & $\begin{array}{l}0.49 \\
\end{array}$ & \begin{tabular}{|l|} 
\\
\end{tabular} & 0.28 & 0.10 & 0.34 & 0.61 & 0.60 & 0.62 & 0.66 & 0.42 & 0.38 & 0.27 & 0.61 & 0.70 & 0.45 & 0.350 & 0.84 & 1.13 & 0.58 & $0.24 \mathrm{C}$ & \begin{tabular}{|l|c|}
0.28 \\
\end{tabular} & \begin{tabular}{|l|c|}
0.82 \\
\end{tabular} & 0.29 & \begin{tabular}{|l|}
0.31 \\
\end{tabular} & & & \\
\hline$F 1(13 \times 24)$ & 1.09 & 1.05 & 1.18 & 1.28 & 1.02 & 0.85 & $0.71 \mathrm{C}$ & 0.85 & 0.70 & 1.33 & 0.92 & 0.98 & 1.48 & 0.72 & 0.87 & 1.020 & 0.80 & 0.84 & 0.88 & 1.201 & \begin{tabular}{|l|l|}
1.13 & \\
\end{tabular} & \begin{tabular}{|l|l|}
1.10 \\
\end{tabular} & 1.29 & \begin{tabular}{|l|l|}
1.12 & \\
\end{tabular} & 1.21 & & \\
\hline$F 1(6 \times 13)$ & 1.44 & 1.40 & 1.46 & \begin{tabular}{|l|}
1.60 \\
\end{tabular} & 1.34 & 1.18 & 1.241 & 1.21 & 1.06 & 1.55 & 1.25 & 1.34 & 1.79 & 0.93 & 1.17 & 1.320 & 0.91 & 1.24 & 1.05 & 1.511 & \begin{tabular}{|l|l}
1.49 \\
\end{tabular} & \begin{tabular}{|l|l}
1.48 \\
\end{tabular} & 1.61 & \begin{tabular}{|l|l|}
1.49 \\
\end{tabular} & 1.53 & 0.7 & \\
\hline$F 1(13 \times 6)$ & 1.20 & 1.11 & 1.12 & \begin{tabular}{|l|}
1.34 \\
\end{tabular} & 1.15 & 0.92 & 1.02 & 1.03 & 0.92 & 1.22 & 0.95 & 1.06 & 1.53 & 0.78 & 0.94 & 1.020 & $0.74 \mathrm{C}$ & 0.94 & 0.71 & 1.191 & \begin{tabular}{|l|l|}
1.13 & \\
\end{tabular} & \begin{tabular}{|l|l}
1.22 \\
\end{tabular} & 1.35 & \begin{tabular}{|l|l|}
1.301 \\
\end{tabular} & 1.26 & 0.75 & 0.57 \\
\hline
\end{tabular}


J. Agric. Sci. Mansoura Univ., 32 (6), june, 2007

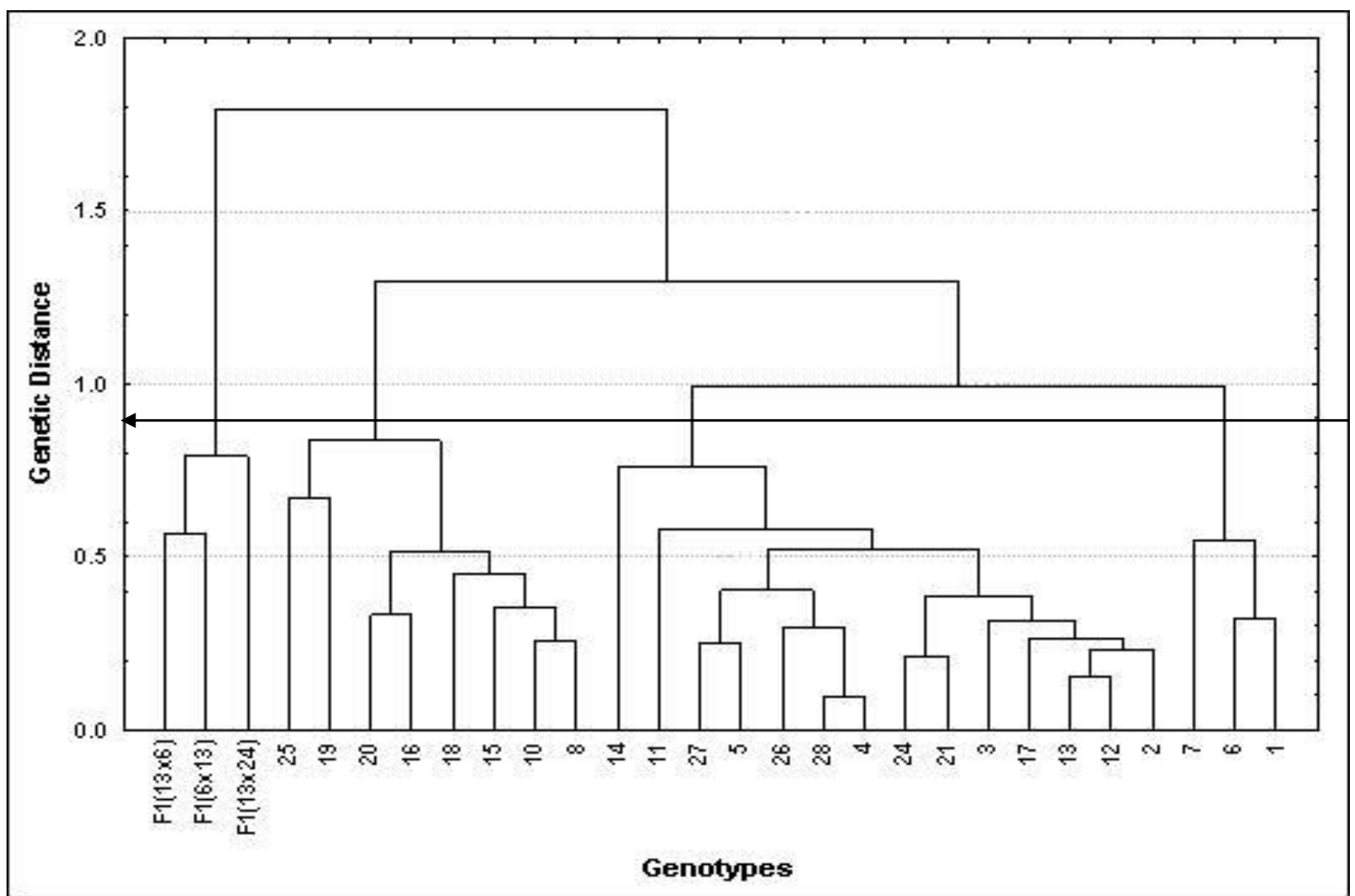

Fig. 3: Linkage dendrogram for twenty-eight local and exotic pea cultivars and $F_{1}$ hybrids, based on transformed mean values of eight developmental, yield and quality characters. 


\section{Swidan, Suzan A.}

Table 5 : Mean values of some developmental, yield and quality characters for local and exotic pea cultivars and F1 hybrids over two clustering systems .

\begin{tabular}{|c|c|c|c|c|c|c|c|c|c|c|}
\hline \multirow[b]{2}{*}{$\begin{array}{c}\text { Cluster } \\
\text { No. }\end{array}$} & \multirow{2}{*}{$\begin{array}{c}\text { Number } \\
\text { Of } \\
\begin{array}{c}\text { Cultivar or } \\
\text { hybrid }\end{array}\end{array}$} & \multirow[b]{2}{*}{$\begin{array}{l}\text { Cultivar or hybrid } \\
\text { ( Population ) }\end{array}$} & \multirow{2}{*}{$\begin{array}{l}\text { Stem } \\
\text { length } \\
(\mathrm{cm})\end{array}$} & \multirow[b]{2}{*}{$\begin{array}{c}\text { No. } \\
\text { leaves/plant }\end{array}$} & \multirow[b]{2}{*}{$\begin{array}{c}\text { No. } \\
\text { Branches/plant }\end{array}$} & \multicolumn{2}{|c|}{ Yield/plant } & \multirow[b]{2}{*}{\begin{tabular}{|l} 
Yield \\
Ton/Fed.
\end{tabular}} & \multicolumn{2}{|c|}{ Pod characters } \\
\hline & & & & & & $\begin{array}{l}\text { Pods wt } \\
\text { (g) }\end{array}$ & $\begin{array}{l}\text { No. } \\
\text { pods }\end{array}$ & & $\begin{array}{l}\text { Weight } \\
\text { (g) }\end{array}$ & $\begin{array}{l}\text { Length } \\
\text { (cm) }\end{array}$ \\
\hline \multicolumn{11}{|c|}{ Clustering of pea populations based on differential expression of esterase molecular forms in four tissues } \\
\hline I & 10 & $\begin{array}{c}1,6 \times 13,3,13 \times 6 \\
13,24,13 \times 24 \\
26,27,28\end{array}$ & 77.72 & 58.3 & 3.37 & 102.10 & 38.63 & 3.15 & 2.12 & 6.49 \\
\hline II & 18 & $\begin{array}{c}2,5,14,15,17 \\
25,18 \\
19,20,21,4,16,6,7 \\
8,10,11,12\end{array}$ & 79.63 & 53.2 & 3.23 & 79.25 & 29.26 & 3.17 & 2.30 & 8.32 \\
\hline \multicolumn{11}{|c|}{ Clustering of pea populations based on transformed mean values of eight developmental, yield and quality characters } \\
\hline 1 & 3 & $1,6,7$ & 85 & 73.3 & 3.55 & 64.63 & 36.23 & 2.54 & 1.58 & 6.29 \\
\hline II & 14 & $\begin{array}{c}2,3,4,5,11,12,13 \\
14,17,21,24,26,27 \\
28\end{array}$ & 69.65 & 40.5 & 2.43 & 52.35 & 22.09 & 2.16 & 2.19 & 7.70 \\
\hline III & 8 & $\begin{array}{c}8,10,15,16,18,19 \\
20,25\end{array}$ & 90.94 & 60.00 & 3.97 & 104.22 & 32.75 & 4.22 & 2.54 & 8.50 \\
\hline IV & 3 & $13 \times 24,6 \times 13,13 \times 6$ & 84.33 & 85.6 & 5.11 & 228.96 & 77.67 & 5.68 & 2.29 & 6.65 \\
\hline
\end{tabular}

